\title{
Condições Sanitárias de Cantinas Escolares do Itapoã e Paranoá-Df Que Integram O Programa Saúde Na Escola
}

\author{
Thelma Machado Gonçalves (I), Verônica Cortez Ginani (I), Diana \\ Lima Reis (I) \\ (I) UnB - Universidade de Brasília (Campus Darcy Ribeiro - Asa Norte)
}

\section{Resumo}

O Programa Nacional de Alimentação Escolar (PNAE) é um programa de abrangência nacional que assegura o direito da alimentação escolar em todas as unidades da rede pública de ensino. Também compõe medidas para promoção da saúde no ambiente escolar, assim como o Programa Saúde na Escola (PSE), que, por sua vez, visa fortalecer ações de educação e saúde. Um ponto de destaque, neste contexto, é a qualidade higiênicosanitária da alimentação ofertada. Sendo assim, o presente estudo teve como objetivo analisar aspectos das condições higiênico-sanitárias de escolas contempladas pelo PNAE e PSE pertencentes a duas regionais do DF. Para tanto, foram analisadas $75 \%(\mathrm{n}=3)$ das escolas assistidas pelo PNAE e pelo PSE na localidade. Inicialmente foi aplicada uma lista de verificação baseada na $R D C n^{\circ} 216 / 2004$ e posteriormente foram coletadas as amostras in loco de superfícies, utensílios e equipamentos para determinação do nível de contaminação microbiológica. Para realização dos ensaios foram utilizados métodos oficiais para detecção de microorganismos indicadores (Coliformes Termotolerantes, Aeróbios Mesófilos (AM) e Psicrotróficos). Os resultados foram insatisfatórios tanto na Lista de Verificação quanto nos ensaios microbiológicos. Todas as escolas foram classificadas como Insatisfatórias em relação às recomendações da ANVISA e nas análises laboratoriais, houve conformidade com os padrões em apenas $43 \%(\mathrm{n}=16)$ das amostras de AM. O único resultado satisfatório foi a contagem de Coliformes Termotolerantes, que apresentou 94\% ( $\mathrm{n}=16)$

\footnotetext{
Referência:

Thelma Machado Gonçalves, Verônica Cortez Ginani, Diana Lima Reis. Condições Sanitárias de Cantinas Escolares do Itapoã e Paranoá-DF que Integram O Programa Saúde na Escola. In: Anais do 12을 Congresso Latinoamericano de Microbiologia e Higiene de Alimentos - MICROAL 2014 [= Blucher Food Science Proceedings, num.1, vol.1]. São Paulo: Editora Blucher, 2014. DOI 10.5151/foodsci-microal-232
} 
das amostras adequadas. Os resultados revelam a necessidade de ações corretivas importantes que devem ser elaboradas de acordo com os dados obtidos. Dessa forma, será possível contribuir com melhorias da qualidade higiênico-sanitárias das refeições ofertadas nas escolas estudadas.

Palavras-Chave: Cantinas escolares, micro-organismos indicadores, qualidade sanitária

Agência de Fomento: 